\title{
Energy Analysis of Greenhouse Dryer for Ficus Carica L. Leaves
}

Wan Nurlaila Mat Desa ${ }^{1}$, Ahmad Fudholi ${ }^{1,2 *}$, Henny Sudibyo ${ }^{2}$, Ghalya Pikra ${ }^{2}$, Nugrahaning Sani Dewi ${ }^{2}$, Nilofar Asim $^{1}$, Dalmasius Ganjar Subagio ${ }^{2}$, Tinton Dwi Atmaja ${ }^{2}$, Edy Riyanto ${ }^{2}$, Kadek Heri Sanjaya ${ }^{2}$, Muhammad Kristiawan $^{3}$, Haznan Abimanyu ${ }^{2}$

${ }^{1}$ Solar Energy Research Institute, Universiti Kebangsaan Malaysia, Bangi Selangor 43600, Malaysia

${ }^{2}$ Research Centre for Electrical Power and Mechatronics, Indonesian Institute of Sciences (LIPI), Bandung 40135, Indonesia

${ }^{3}$ Universitas Bengkulu, Bengkulu 38371, Indonesia

Corresponding Author Email: a.fudholi@gmail.com

https://doi.org/10.18280/ijht.390314

Received: 25 April 2021

Accepted: 31 May 2021

\section{Keywords:}

thermal energy, solar energy, solar drying, solar collector, thermal efficiency

\begin{abstract}
In this study, a greenhouse solar dryer with double-pass multi-hollow collector for leaf drying was design, constructed, and evaluated. From the result, the double pass solar air collector with multi-hollow tube is capable of increasing air temperature by $5.5^{\circ} \mathrm{C}-10.8^{\circ} \mathrm{C}$ compared to ambient air temperature. Thermal efficiency of the dryer was evaluated for passive and active modes, where $47.2 \%$ and $50 \%$ are recorded respectively. The moisture reduction on mass basis in passive and active dryer recorded was $44 \%$ and $74 \%$, respectively. The specific moisture extraction rate (SMER) and specific energy consumption (SEC) of passive dryer was determined to be $0.198 \mathrm{~kg}$ per $\mathrm{kWh}$ and 5.047 $\mathrm{kWh}$ per kg, and active dryer at $0.210 \mathrm{~kg}$ per $\mathrm{kWh}$ and $4.769 \mathrm{kWh}$ per kg, respectively.
\end{abstract}

\section{INTRODUCTION}

Food preservation is an important aspect of live, where human diet and overall health wellbeing is dependent upon. Most importantly, food preservation is essential to ensure adequate food supply that is capable to meet the demand of growing population around the world. The importance of food preservation is extended to ensure balance global food supplydemand, by preventing post-harvest losses of the agriculture sector thus enabling longer storage period of food commodities. Food preservation processes also produces value-added products, high quality food and contributes to variation in diet. Overall, the experience of eating is highly improved through food preservation techniques as it provides improved nutritional values, and in some parts of the world especially developing countries, food variation further leads to lower reliance on staple commodities $[1,2]$.

As agriculture industry produces raw food materials, inadequate management of agricultural produce can be avoided by increasing the storage life through simple methods of preservation. Drying is a one of the process of preservation, which have been practiced from time immemorial. The main mechanism of drying process is removal of excess moisture from drying samples, which is used slow microbial growth that causes degradation and spoilage in the first place. In preserving food, important considerations which must be made are (i) the desired level of quality (ii) the preservation length (iii) the group for whom the products are preserved. Drying is proven to be capable of meeting the aforementioned criteria, thus it is widely applied in agricultural industry. To date, drying is used to produce wide range of agricultural produce, including fruits, vegetable, herbs, marine and poultry [2-7].

Despite the high reliability of in producing good product quality and reducing raw material losses, drying is a highly energy intensive process. The inherent high energy consumption in drying process is due to overcoming the high latent heat in removing moisture from products. In developed countries where technology is advanced such as the US, Germany, UK and France, drying of food products consumes $7-15 \%$ of industrial energy [8]. The value is much higher for developing countries, where drying process consumes about $50 \%$ of the food processing sector [9]. As drying is an energy intensive process, it leads to another concern on environmental implication of carbon emission related to the energy generation. Therefore, conventional energy generation intended for drying process is undesirable in the long run.

Solar energy provides an alternative to conventional drying, where it can supply clean energy to meet the demand for drying process. Solar drying can be broken down into two types; open sun drying and solar-assisted drying system. The former is a traditional method of sun drying which is the simplest and most cost effective, however it is also highly unreliable as it completely depends on climate conditions. Numerous research and efforts are now being put to develop the latter category, where solar-assisted drying systems are believed to be able to overcome the limitations of open sun drying and conventional drying system. Solar-assisted dryer systems consist of two major components; solar collector unit and drying chamber to effectively increase drying air temperature compared to surrounding air, thus facilitating faster moisture removal process. Solar collector unit function can be defined as a special energy exchanger, where it converts solar irradiation to thermal energy of the working fluid [10]. A typical solar collector unit is made up of an absorber plate, transparent glazing cover, and insulation layer. Depending of intended application and desired temperature increase, a solar collector unit can be concentrating or flat-plate type. The former can produce higher output temperature; commonly used in large scale solar farms and coupled with sophisticated 
sun tracking system, additional lenses and mirrors. Meanwhile, the latter is capable of producing moderate output temperature and commonly used for low temperature applications such as domestic water heating and space heating. For agricultural drying, solar drying system with air based solar collectors have been reviewed by Fudholi et al. [11]. Suitable designs of solar collector unit fit this drying purpose are SDS with (i) V-groove solar collectors, (ii) finned double-pass solar collectors, (iii) double-pass collector containing an integrated storage system, and (iv) photovoltaic thermal (PVT) collector [11].

Table 1. The advantages and disadvantages of passive (natural) mode solar greenhouse dryer

\begin{tabular}{|c|c|c|}
\hline $\begin{array}{c}\text { Advantages/ } \\
\text { disadvantages }\end{array}$ & Description & Ref. \\
\hline \multicolumn{3}{|c|}{$\begin{array}{l}\text { Easy to install and to operate especially wh } \\
\text { no electrical grid exists. } \\
\text { - Best for low moisture content crops. }\end{array}$} \\
\hline \multicolumn{3}{|c|}{$\begin{array}{l}\text { Table 2. The advantages and disadvantages of active (forced) } \\
\text { mode solar greenhouse dryer }\end{array}$} \\
\hline $\begin{array}{c}\text { Advantages/ } \\
\text { disadvantages }\end{array}$ & Description & Ref. \\
\hline Advantages & $\begin{array}{l}\text { - Drying rate is faster than passive } \\
\text { mode. } \\
\text { - Best suits for high moisture content } \\
\text { crops. }\end{array}$ & $\begin{array}{r}{[16,} \\
18]\end{array}$ \\
\hline Disadvantages & $\begin{array}{l}\text { - More complicated than passive mode. } \\
\text { - More expensive as they need fans/ } \\
\text { blower, ventilators for air circulating } \\
\text { and piping loops. }\end{array}$ & [14] \\
\hline
\end{tabular}

Table 3. The advantages and disadvantages of hybrid solar greenhouse dryer

\begin{tabular}{ccc}
$\begin{array}{c}\text { Advantages/ } \\
\text { disadvantages }\end{array}$ & Description & Ref. \\
& $\begin{array}{c}\text { Drying time, drying rate and energy } \\
\text { consumption were reduced. }\end{array}$ & \\
Advantages & $\begin{array}{c}\text { - The drying could be operated when } \\
\text { adverse weather conditions exist by } \\
\text { using a supplementary heat source as a }\end{array}$ & 20] \\
& $\begin{array}{c}\text { back-up to solar radiation. } \\
\text { - May lead to fuel dependent. }\end{array}$ \\
Disadvantages & - Build and maintenance costs are \\
& \multicolumn{2}{c}{ expensive } \\
\hline
\end{tabular}

Greenhouse dryer system is a type of mixed-mode system, where it combines the operation of solar collector with greenhouse system [12]. The construction of a greenhouse dryer combines the function of the solar collector with a greenhouse system. The roof and wall of the dryer is made using transparent materials, such as glass, fibre glass, UV stabilized plastic or polycarbonate sheets. The transparent materials are fixed on a steel frame support or pillars with bolts and nuts and sealing to prevent humid air or rain water leaking into the chamber other than those introduced from the inlet opening. The working principle of a greenhouse system is based on the greenhouse effect, where its transparent walls allow incoming shortwave solar radiation to be converted into longwave radiation, thus trapping the radiation inside its confined walls. To increase solar radiation absorption, black surfaces should be provided within the structure. Inlet and exhaust fans are placed at proper position within the structure to guarantee even distribution of the drying air. If designed properly, greenhouse dryers can allow a greater degree of control over the drying process than the cabinet dryers and they will be more appropriate for large scale drying. Greenhouse dryers are observed to have various advantages over other type of dryers; it provides the best quality, color and taste of the dried products [13]. In literature, there has been many studies done on solar greenhouse dryers to improve its performance, thus leading to diverse system modifications. Tables 1-3 shows the comparisons on the advantages and disadvantages of various types of solar greenhouse dryer. However, this study focusses on the evaluation of a solar drying system to analyse energy requirement and thermal performance of portable mixed mode greenhouse dryer with double pass collector system by using energy analysis.

\section{MATERIALS AND METHOD}

Greenhouse solar dryer system constructed for this research consists of 3 major components; solar collector unit, drying chamber unit, and ventilation unit. The design of this dryer also takes into account for portability, thus wheels were installed to ease the movement of this system, as shown in Figure 1 and Figure 2. The solar collector unit used in this research adopts the double-pass collector design, where inlet air will travel through two travel passages; upper and lower channel. The components of the solar components consist of transparent glazing, solar absorber flat plate, and insulation layer. The outermost cover of the collector uses transparent glazing, which in this case is tempered glass of unknown transmissivity. The application of tempered glass is selected to prevent material degradation due to outdoor climatic exposure. Solar absorber flat-plat layer is constructed using aluminium plates, with additional multi-hollow tubes on the lower channel, as shown in Figure 2. The purpose of adding two layers of hollow tubes as fin structure on the absorber is to increase the effective area for heat transfer process. The design and construction of the dryer system were done in Bengkel Fizik, Fakulti Sains dan Teknologi, Universiti Kebangsaan Malaysia.

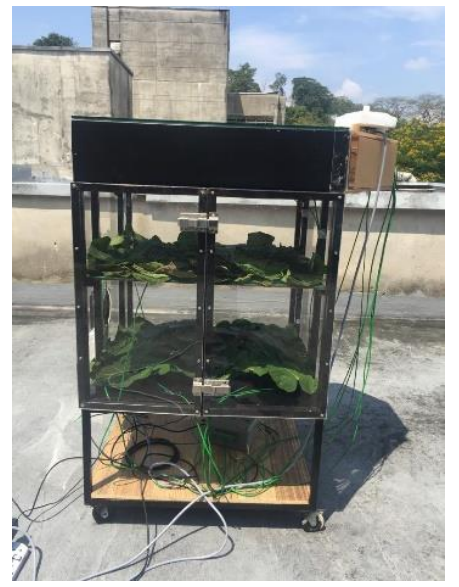

Figure 1. Photograph of greenhouse dryer consisting of solar collector attached to the drying chamber 


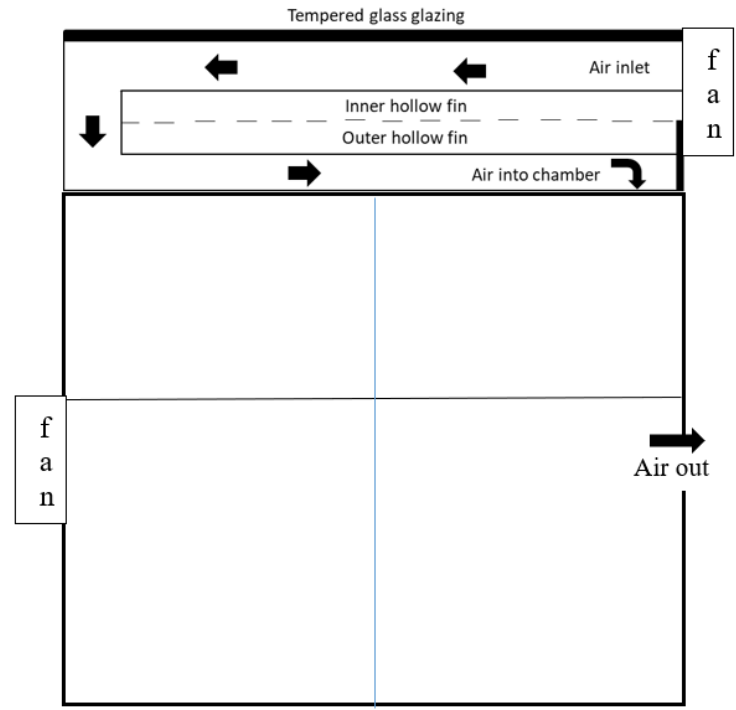

Figure 2. Schematic of greenhouse dryer consisting of solar collector attached to the drying chamber

Figure 3 shows the four steps are the order of experimental procedure to study the energy analysis of the greenhouse solar dryer. Prior to the experimental start-up, instruments and electrical connections were put in place.

(i) Greenhouse solar dryer in passive mode without any load is placed in the open field at 11AM - 4PM.

(ii) Data for ambient and system variables are recorded at every 2-minute interval from beginning to the end of experiment. Solar irradiation was recorded using pyranometer integrated with data logger. System variables recorded were temperature of solar collector unit i.e. glass glazing and hollow tubes, outlet air from collector, outlet air from chamber, and inside chamber temperature.

(iii) The experiment is repeated in active mode, where ventilation unit is installed to the collector unit. With similar set-up, the fans are activated to create faster airflow. For active mode, the mass flow rate of air is adjusted and kept constant at $0.056 \mathrm{~kg} / \mathrm{s}$.

(iv) Step $1-3$ are repeated with drying samples. 500 grams of Ficus carica L. leaves are placed on the drying tray. The samples are left in the drying chamber for 6 hours before the dryer was turned off at 4PM. The final weight of the samples is recorded to determine the moisture reduction mass.

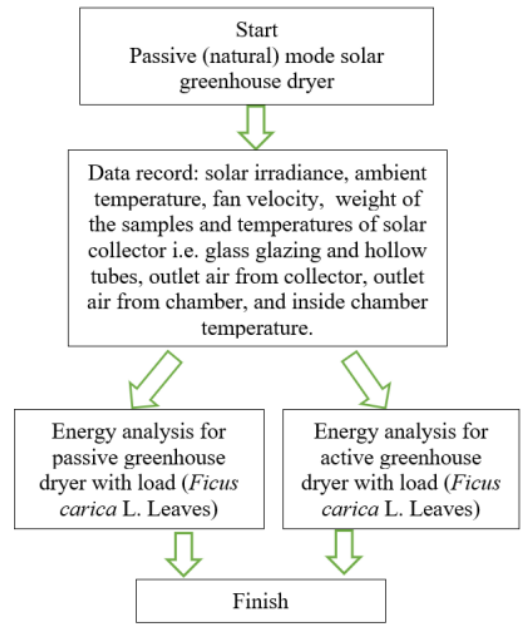

Figure 3. Flowchart of experimental procedure to study the energy analysis of the greenhouse solar dryer
The thermal efficiency of a solar collector is defined as the ratio of heat gained by air passing through the collector to the energy gained from solar irradiation, expressed as a percentage [22-24].

$$
\eta_{c}=\frac{m c\left(T_{o u t}-T_{\text {in }}\right)}{A_{c} I} \times 100 \%
$$

Another indicator commonly used in energetic analysis is the thermal efficiency of solar dryers, $\eta_{d}$. Essentially, $\eta_{d}$ is the ratio of energy required to evaporate product's moisture to the energy consumed for the drying process. In short, thermal efficiency of the drying system is the ratio of the energy used for moisture evaporation to the energy input to the drying system.

The drying efficiency of solar dryer, $\eta_{d}$ is another measure widely used in energetic analysis, which it is the ratio of the energy needed to evaporate the moisture in a commodity to the energy consumed during the drying process. In a nutshell, the drying system's thermal efficiency is the ratio of the energy used for moisture evaporation to the energy supply.

$$
\eta_{d}=\frac{E_{\text {evap }}}{E_{\text {input }}}
$$

The energy input through electrical fans or blowers is taken into account in passive convection dryers, while active dryers take into account the energy input through electrical fans or blowers, which is provided by respectively [25, 26]. The energy consumed for the drying process will need to account for all sources of energy produced in the system, depending on the type of solar drying system. In hybrid systems, such as photovoltaic-thermal (PVT) hybrid dryers, the solar collector's electrical efficiency is measured as the device converts electricity into energy [27-30].

$$
\begin{gathered}
\eta_{d, P}=\frac{m L_{v}}{A_{c} I t_{d}} \\
\eta_{d, A}=\frac{m L_{v}}{A_{c} I+P_{f}} \\
\eta_{d, H}=\frac{m L_{v}}{A_{c} I+P_{f}+P_{h}}
\end{gathered}
$$

The relationship between the amount of water evaporated and the amount of energy input to the solar dryer can also be used to describe the dryer's efficiency and to compare the performance of different dryers. The specific moisture extraction rate (SMER) in $\mathrm{kg} \mathrm{kW} / \mathrm{h}$ refers to the amount of moisture that can be extracted per unit of energy. SMER stands for SDS effectiveness, which is described as the amount of energy needed to extract $1 \mathrm{~kg}$ of water. The reversal effect on real energy consumption is also expressed in this variable (SEC). Specifically, specific energy consumption (SEC) is the reciprocal of SMER in $\mathrm{kWh} / \mathrm{kg}$ units [27-31].

$$
\begin{aligned}
& \text { SMER }=\frac{\text { Amount of moisture evaporated }}{\text { Energy input to the dryer }}=\frac{W}{P_{t}} \\
& S E C=\frac{\text { Energy input to the dryer }}{\text { Amount of moisture evaporated }}=\frac{P_{t}}{W}
\end{aligned}
$$




\section{RESULTS AND DISCUSSION}

Weather parameters i.e. ambient temperature and solar irradiation were recorded to determine its variation on the performance of the dryer. These data measurements are done using three thermocouples that were attached to the air inlet of the collector unit. Figure 4a corresponds to a typically day with few cloud interferences, while Figure $4 b$ shows the profile of a cloudier days, which eventually resulted in rain. Figure $4 \mathrm{c}$ on the other hand indicates sunny day with clear sky.

During the experimentation, thirteen thermocouples were attached on the glass cover, aluminum collector plate, air inlet into the chamber, inside the chamber, and around air outlet. The temperature data are plotted in respect to solar irradiance reading, as shown in Figure 5.

As for the temperature increase of air from collector, the double pass with multi-hollow tube is shown to be able to increase air temperature between $5.5^{\circ} \mathrm{C}-10.8^{\circ} \mathrm{C}$ compare to the ambient air temperature. The highest temperature recorded for Trial 1 and Trial 2 were $51.9^{\circ} \mathrm{C}$ and $53.1^{\circ} \mathrm{C}$, respectively. This range of values shows that the system can provide the optimum drying temperature for leaf drying, which is $40-60^{\circ} \mathrm{C}$, where $50^{\circ} \mathrm{C}$ is known to cause minimal loss of quality [32].

(a)
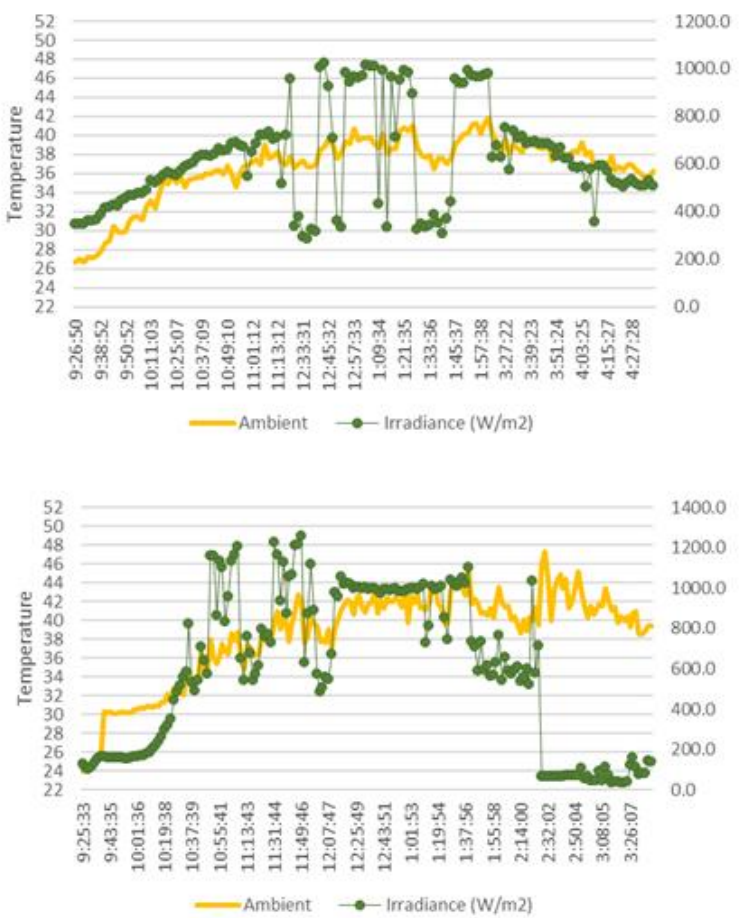

(b)

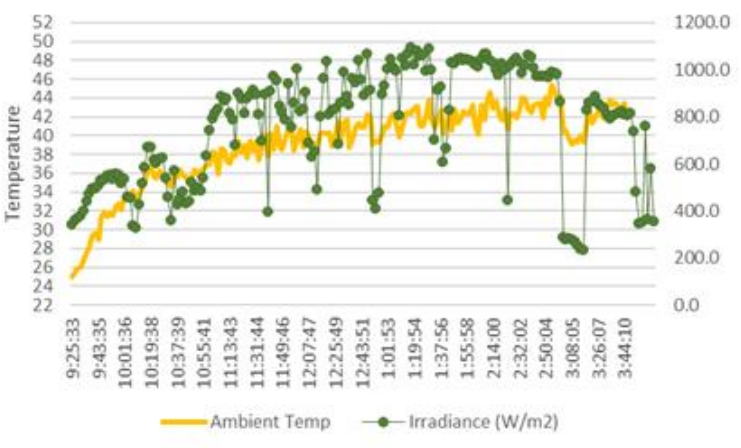

Figure 4. Weather pattern using ambient temperature and solar irradiance on days of experimentation a) 5 March b) 6 March c) 8 March
Under two ventilation modes i.e. active and passive, different temperature profile is obtained. Active mode refers to forced convection, where fans were used to facilitate air movement. Passive mode on the other hand relies completely on the natural movement of air. Figure 5a shows that the inlet air temperature into the dryer is much higher compared to ambient air and air at outlet and inside chamber. It can be observed here that passive mode contributes to steeper temperature gradient between hot air entering the chamber to other temperature points in the system. In active ventilation mode, the temperature profile shows readings of similar values throughout measurement points of the system. This indicates that the heat distribution in active dryers is more uniform compared to passive dryers. Despite the difference, the temperature profile also shows similarities in fluctuations throughout the day. Both ventilation modes show similar relationship between solar irradiance and temperature readings. The change in solar irradiance resulted in almost instantaneous temperature change. In the findings by Wang et al. [33], it is explained that when irradiance changes rapidly in a short time the instantaneous heat remains stable, due to the collector has a certain heat capacity. Hence, when the solar radiation sharply fluctuates the solar collector can provide a constant heat. Therefore, the temperature profile of this dryer indicates that the system is very sensitive to solar irradiance change. This is likely due to inefficient insulation system, and the absence of energy storage system.

a)

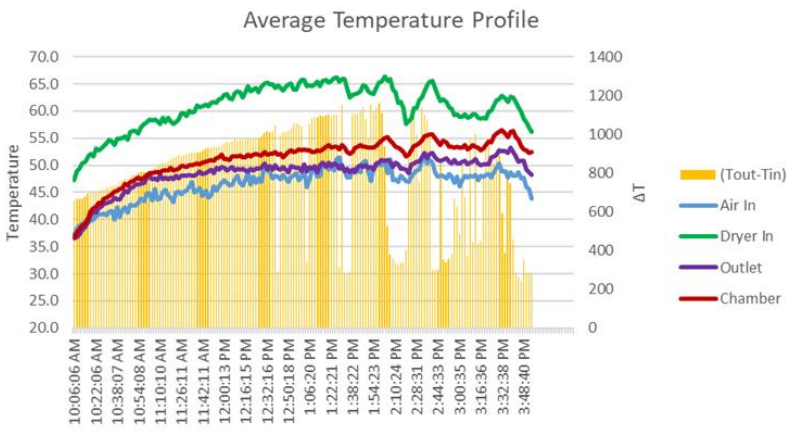

b)

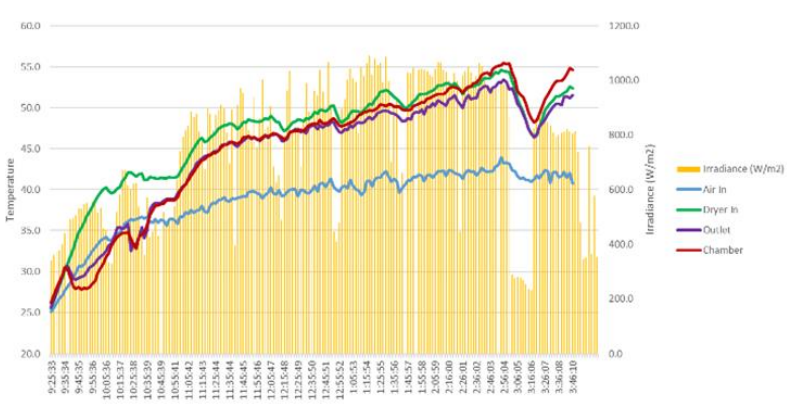

Figure 5. Temperature profile of the inside of drying chamber in a) passive and b) active condition

Table 4. Solar collector efficiency for double pass multi hollow tube collector unit

\begin{tabular}{ccccc}
\hline & \multicolumn{3}{c}{ Trial 1 } & \multicolumn{2}{c}{ Trial 2 } \\
\cline { 2 - 5 } Time & $\begin{array}{r}\text { IrradianceCollector Efficiency } \\
\left(\mathrm{W} / \mathrm{m}^{2}\right)\end{array}$ & $(\%)$ & $\left(\mathrm{W} / \mathrm{m}^{2}\right)$ & $\begin{array}{c}\text { Irradiance } \\
(\%)\end{array}$ \\
\hline 11 AM & 581.3 & 48.2 & 516.3 & 44.6 \\
12 PM & 685.9 & 51.5 & 838.2 & 41.9 \\
1 PM & 665.0 & 58.7 & 816.1 & 46.5 \\
2 PM & 739.8 & 53.0 & 977.0 & 41.5 \\
3 PM & 683.4 & 54.6 & 992.5 & 45.1 \\
4 PM & 529.9 & 63.2 & 630.0 & 73.2 \\
\hline
\end{tabular}


Solar collector efficiency is the heat gain by drying air over heat available at solar collector. In this experiment, a couple of trials were performed to determine the solar collector efficiency. The thermal performance of the solar collector has been analysed with a stable mass flow rate of air of $0.056 \mathrm{~kg} / \mathrm{s}$. The results obtained are summarized in Table 4. The collector efficiencies are calculated in respect to hourly average solar irradiance value. This way the hourly efficiency for each drying day is plotted, as shown in Figure 6. From the experimentation, the solar collector efficiency calculated ranges from $41.9 \%$ to $73.2 \%$, while the solar irradiance ranges from 516.3 to $992.5 \mathrm{~W} / \mathrm{m}^{2}$. Overall, the solar collector shows adequate heating capacity as the collector efficiency calculated is in the range of values reported in literature, where most solar collector operates at 33-56\% [11]. As for the temperature increase provided by the collector, the double pass with multihollow tube is shown to be able to increase air temperature between $5.5^{\circ} \mathrm{C}-10.8^{\circ} \mathrm{C}$ compare to the ambient air temperature. The highest temperature recorded for Trial 1 and Trial 2 were $51.9^{\circ} \mathrm{C}$ and $53.1^{\circ} \mathrm{C}$, respectively.

From Figure 5, the collector efficiency records low values at Hour 1 (11AM) and Hour 6 (4PM), while it fluctuates in between. During evening, the efficiency is much lower despite having the highest solar irradiance reading. This trend is observed for both Trial 1 and 2. This trend is unexpected, as the efficiency normally increases with solar irradiance reading.

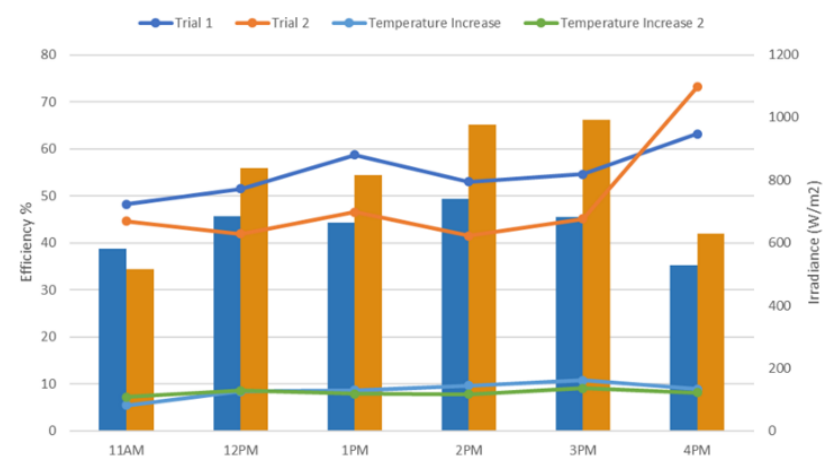

Figure 6. Solar collector efficiency and solar irradiance over time of the day

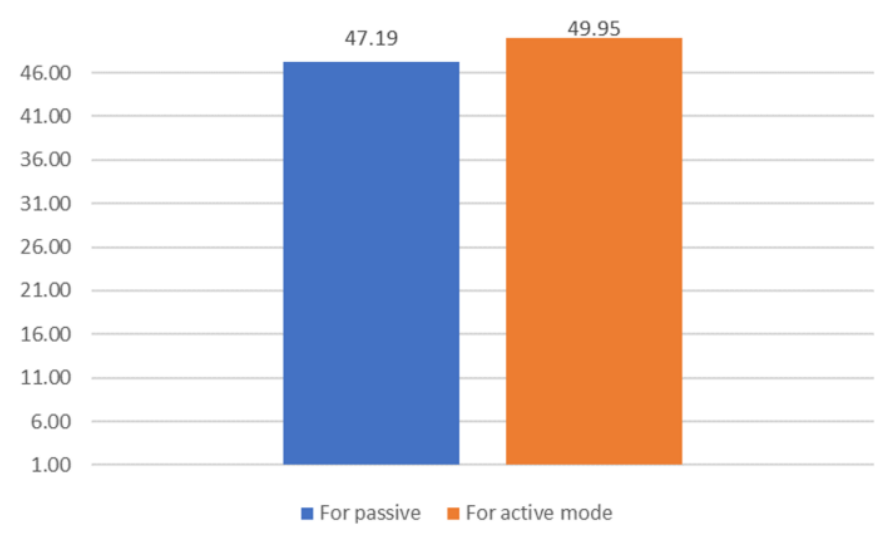

Figure 7. Dryer thermal efficiency of solar dryer in passive and active mode

Dryer efficiency of solar dryer system is also known as the thermal efficiency. The calculation for this performance indicator can be made for both of dryer mode of operation; active and passive air circulation. The thermal efficiency of solar dryer is evaluated as the amount of energy needed to vaporize moisture over the energy made available to the dryer. In both of these energy analyses, 500 gram of Ficus carica $\mathrm{L}$. leaves were used as drying sample. Active dryer evaporated a total mass of $370 \mathrm{~g}$ of water, resulting in $74 \%$ mass reduction of the sample. Whereas passive dryer recorded $44 \%$ mass reduction, where $220 \mathrm{~g}$ of water was evaporated. Figure 7 shows the bar chart of the thermal efficiency calculated for both ventilation modes. The active mode records a thermal efficiency of $50 \%$, while the passive is at $47.2 \%$. From these values, passive mode has $5 \%$ lower efficiency compared to active. Under similar weather conditions, active dryer shown to be more effective than passive dryer.

Specific moisture extraction rate (SMER) is one of the indicators used to define the performance of a dryer. It refers to the amount of moisture extracted per $\mathrm{kWh}$ of energy. The reciprocal of SMER is known as specific energy consumption (SEC), defined as energy required to evaporate $1 \mathrm{~kg}$ of moisture. The values of SMER and SEC is given in Table 5. For this dryer system, the SMER value is calculated to be 0.210 and $0.198 \mathrm{~kg}$ water per $\mathrm{kWh}$ of energy consumed for active and passive dryer, respectively. The SEC of this dryer was determined at 4.769 and $5.047 \mathrm{kWh}$ per $1 \mathrm{~kg}$ of moisture evaporated. Active dryer is shown to be more energy efficient, with $5.52 \%$ for higher SMER and lower SEC than passive dryer.

Table 5. Parameters and calculations for SMER and SEC of the greenhouse dryers

\begin{tabular}{ccc}
\hline Parameter & Active & Passive \\
\hline Mass of water $(\mathrm{kg})$ & 0.37 & 0.22 \\
Energy for moisture evaporated $(\mathrm{kWh})$ & 1.764 & 1.110 \\
SMER $(\mathrm{kg} / \mathrm{kWh})$ & 0.210 & 0.198 \\
SEC $(\mathrm{kWh} / \mathrm{kg})$ & 4.769 & 5.047 \\
\hline
\end{tabular}

\section{CONCLUSIONS}

Based on field trials, the double pass solar air collector with multi-hollow tube is capable of increasing air temperature by $5.5^{\circ} \mathrm{C}-10.8^{\circ} \mathrm{C}$ compared to ambient air temperature. The highest chamber temperature recorded by this dryer system was $51.9^{\circ} \mathrm{C}$ and $53.1^{\circ} \mathrm{C}$, in passive and active mode respectively. The thermal efficiency of solar collector was determined to be 41.9 to $73.2 \%$ at corresponding solar irradiance of 516.3 to $992.5 \mathrm{~W} / \mathrm{m}^{2}$. However, there is a weak correlation between the thermal efficiency and solar irradiance, where efficiency fluctuates with changing solar intensity. This can be explained by inadequate thermal insulation and the absence of energy storage system. Thermal efficiency of the dryer was evaluated for passive and active modes, where $47.2 \%$ and $50 \%$ are recorded respectively. The moisture reduction on mass basis in passive and active dryer recorded was $44 \%$ and $74 \%$, respectively. The SMER and SEC of passive dryer was determined to be $0.198 \mathrm{~kg}$ per $\mathrm{kWh}$ and $5.047 \mathrm{kWh}$ per $\mathrm{kg}$, and active dryer at $0.210 \mathrm{~kg}$ per $\mathrm{kWh}$ and $4.769 \mathrm{kWh}$ per $\mathrm{kg}$, respectively.

\section{ACKNOWLEDGMENT}

The authors would like to thank the UKM for funding GP2020-K020448. 


\section{DECLARATIONS}

All authors contributed equally as the main contributor of this study.

\section{REFERENCES}

[1] Desa, W.N.Y.M., Mohammad, M., Fudholi, A. (2019). Review of drying technology of fig. Trends in Food Science \& Technology, 88: 93-103. https://doi.org/10.1016/j.tifs.2019.03.018

[2] Rahman, M.S. (2007). Handbook of Food Preservation. CRC Press.

[3] Fudholi, A., Sopian, K. (2019). A review of solar air flat plate collector for drying application. Renewable and Sustainable Energy Reviews, 102: 333-345. https://doi.org/10.1016/j.rser.2018.12.032

[4] Yahya, M., Fahmi, H., Fudholi, A., Sopian, K. (2018). Performance and economic analyses on solar-assisted heat pump fluidised bed dryer integrated with biomass furnace for rice drying. Solar Energy, 174: 1058-1067. https://doi.org/10.1016/j.solener.2018.10.002

[5] Yahya, M., Fudholi, A., Sopian, K. (2017). Energy and exergy analyses of solar-assisted fluidized bed drying integrated with biomass furnace. Renewable Energy, 105: 22-29. https://doi.org/10.1016/j.renene.2016.12.049

[6] Yahya, M., Fudholi, A., Hafizh, H., Sopian, K. (2016). Comparison of solar dryer and solar-assisted heat pump dryer for cassava. Solar Energy, 136: 606-613. https://doi.org/10.1016/j.solener.2016.07.049

[7] Fudholi, A., Sopian, K., Ruslan, M.H., Alghoul, M.A., Sulaiman, M.Y. (2010). Review of solar dryers for agricultural and marine products. Renewable and Sustainable Energy Reviews, 14(1): 1-30. https://doi.org/10.1016/j.rser.2009.07.032

[8] Sansaniwal, S.K., Sharma, V., Mathur, J. (2018). Energy and exergy analyses of various typical solar energy applications: A comprehensive review. Renewable and Sustainable Energy Reviews, 82: 1576-1601. https://doi.org/10.1016/j.rser.2017.07.003

[9] Sreekumar, A., Rajarajeswari, K. (2018). Accelerated food processing through solar drying system. In IOP Conference Series: Materials Science and Engineering, 377(1): $\quad 012218 . \quad$ https://doi.org/10.1088/1757899X/377/1/012218

[10] Selvaraj, M., Sadagopan, P. (2017). A Review of Solar Energy Drying Technology with Air Based Solar Collectors. Advances in Natural and Applied Sciences, 11(4): 472-478.

[11] Fudholi, A., Sopian, K., Bakhtyar, B., Gabbasa, M., Othman, M.Y. Ruslan, M.H. (2015). Review of solar drying systems with air based solar collectors in Malaysia. Renewable and Sustainable Energy Reviews, 51:

1191-1204 https://doi.org/10.1016/j.rser.2015.07.026

[12] El Hage, H., Herez, A., Ramadan, M., Bazzi, H. Khaled, M. (2018). An investigation on solar drying: A review with economic and environmental assessment. Energy, 157:

815-829. https://doi.org/10.1016/j.energy.2018.05.197

[13] Singh, P., Shrivastava, V. Kumar, A. (2018). Recent developments in greenhouse solar drying: A review. Renewable and Sustainable Energy Reviews, 82: 3250-
3262. https://doi.org/10.1016/j.rser.2017.10.020

[14] Belessiotis, V., Delyannis, E. (2011). Solar drying. Solar Energy, 85(8): 1665-1691.

[15] Basunia, M.A., Abe, T. (2001). Thin-layer solar drying characteristics of rough rice under natural convection. Journal of Food Engineering, 47(4): 295-301.

[16] Kumar, A., Shrivastava, V. (2017). Historical trends and recent developments in solar greenhouse dryer operated under active mode: A review. Indian Journal of Science and Technology, 10(33): 10-17485.

[17] Jain, D., Tiwari, G. (2004). Effect of greenhouse on crop drying under natural and forced convection I: Evaluation of convective mass transfer coefficient. Energy Conversion and Management, 45: 765-783. https://doi.org/10.1016/S0196-8904(03)00178-X

[18] Pratiksha Verma, N. (2016). A review paper on solar greenhouse dryer. IOSR Journal of Mechanical and Civil Engineering, 2(2): 43-48. https://doi.org/10.1016/j.rser.2013.08.084

[19] Vijayavenkataraman, S., Iniyan, S., Goic, R. (2012). A review of solar drying technologies. Renewable and Sustainable Energy Reviews, 16(5): 2652-2670. https://doi.org/10.1016/j.rser.2012.01.007

[20] Amer, B.M.A., Gottschalk, K., Hossain, M.A. (2018). Integrated hybrid solar drying system and its drying kinetics of chamomile. Renewable Energy, 121: 539-547. https://doi.org/10.1016/j.renene.2018.01.055

[21] El Hage, H., Herez, A., Ramadan, M., Bazzi, H., Khaled, M. (2018). An investigation on solar drying: A review with economic and environmental assessment. Energy, 157:

815-829. https://doi.org/10.1016/j.energy.2018.05.197

[22] Fudholi, A., Sopian, K., Alghoul, M.A., Ruslan, M.H., Othman, M.Y. (2015). Performances and improvement potential of solar drying system for palm oil fronds. Renewable Energy, 78: 561-565. https://doi.org/10.1016/j.renene.2015.01.050

[23] Kumar, M., Sansaniwal, S.K., Khatak, P. (2016). Progress in solar dryers for drying various commodities. Renewable and Sustainable Energy Reviews, 55: 346360. https://doi.org/10.1016/j.rser.2015.10.158

[24] Lingayat, A., Chandramohan, V.P., Raju, V.R.K. (2017). Design, development and performance of indirect type solar dryer for banana drying. Energy Procedia, 109: 409-416. https://doi.org/10.1016/j.egypro.2017.03.041

[25] Abubakar, S., Umaru, S., Kaisan, M.U., Umar, U.A., Ashok, B., Nanthagopal, K. (2018). Development and performance comparison of mixed-mode solar crop dryers with and without thermal storage. Renewable Energy, 128: 285-298. https://doi.org/10.1016/j.renene.2018.05.049

[26] Prakash, O., Kumar, A., Laguri, V. (2016). Performance of modified greenhouse dryer with thermal energy storage. Energy Reports, 2: 155-162. https://doi.org/10.1016/j.egyr.2016.06.003

[27] Fudholi, A., Bakhtyar, B., Saleh, H., Ruslan, M.H., Othman, M.Y., Sopian, K. (2016). Drying of salted silver jewfish in a hybrid solar drying system and under open sun: Modeling and performance analyses. International Journal of Green Energy, 13(11): 1135-1144. https://doi.org/10.1080/15435075.2016.1175347

[28] Fudholi, A., Sopian, K., Gabbasa, M., Bakhtyar, B., Yahya, M., Ruslan, M.H., Mat, S. (2015). Technoeconomic of solar drying systems with water based solar 
collectors in Malaysia: A review. Renewable and Sustainable Energy Reviews, 51: 809-820. https://doi.org/10.1016/j.rser.2015.06.059

[29] Fudholi, A., Sopian, K., Othman, M.Y., Ruslan, M.H. (2014). Energy and exergy analyses of solar drying system of red seaweed. Energy and Buildings, 68: 121129. https://doi.org/10.1016/j.enbuild.2013.07.072

[30] Fudholi, A., Sopian, K., Yazdi, M.H., Ruslan, M.H., Gabbasa, M., Kazem, H.A. (2014). Performance analysis of solar drying system for red chili. Solar Energy, 99: 4754. https://doi.org/10.1016/j.solener.2013.10.019

[31] Phahom, T., Phoungchandang, S., Kerr, W.L. (2017). Effects of steam-microwave blanching and different drying processes on drying characteristics and quality attributes of Thunbergia laurifolia Linn. leaves. Journal of the Science of Food and Agriculture, 97(10): 32113219. https://doi.org/10.1002/jsfa.8167

[32] Babu, A.K., Kumaresan, G., Raj, V.A.A., Velraj, R. (2018). Review of leaf drying: Mechanism and influencing parameters, drying methods, nutrient preservation, and mathematical models. Renewable and Sustainable Energy Reviews, 90: 536-556. https://doi.org/10.1016/j.rser.2018.04.002

[33] Wang, W., Li, M., Hassanien, R.H.E., Wang, Y., Yang, L. (2018). Thermal performance of indirect forced convection solar dryer and kinetics analysis of mango. Applied Thermal Engineering, 134: 310-321. https://doi.org/10.1016/j.applthermaleng.2018.01.115 